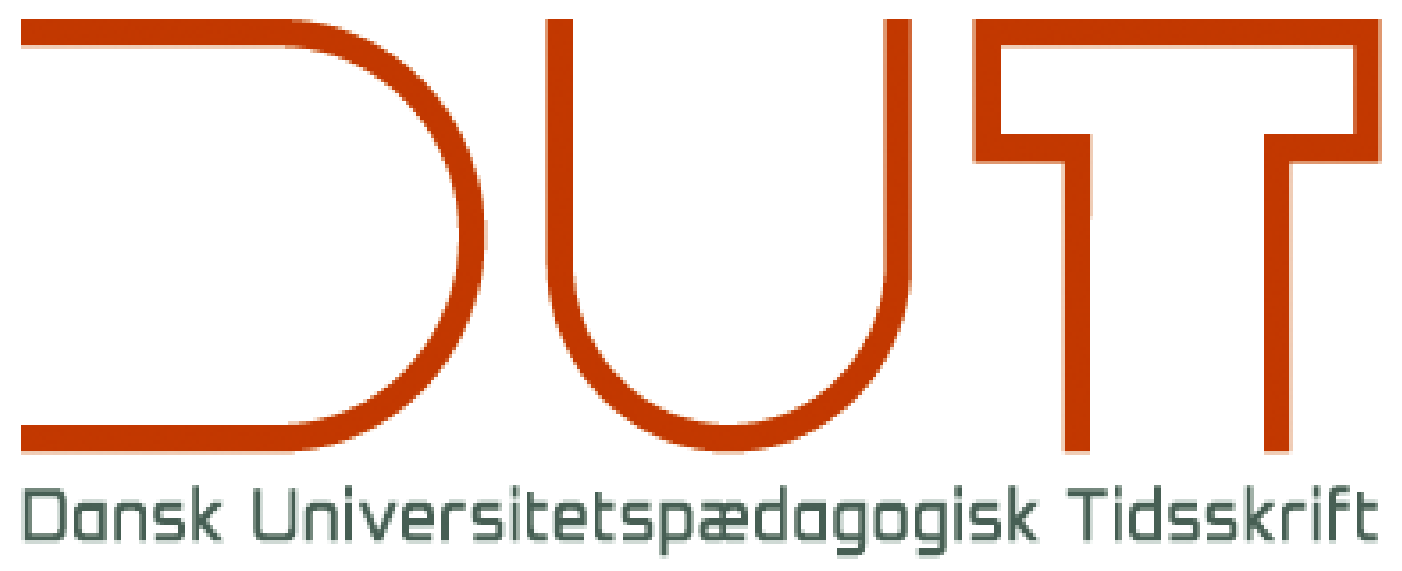

Tema

Nye perspektiver på evalueringsformer i universitetspædagogik

Årgang 12 nr. 23 / 2017

Titel

At lære sig "de kloge damers" sprog: Studerendes perspektiver på akademisk skrivning

Forfatter

Nana Clemensen og Lars Holm

Sidetal

$37-51$

Udgivet af

Dansk Universitetspædagogisk Netværk, DUN

URL

> http://dun-net.dk/

Betingelser for brug af denne artikel

Denne artikel er omfattet af ophavsretsloven, og der må citeres fra den. Følgende betingelser skal dog være opfyldt:

- Citatet skal være i overensstemmelse med „god skik“

- Der må kun citeres „i det omfang, som betinges af formålet"

- Ophavsmanden til teksten skal krediteres, og kilden skal angives ift. ovenstående bibliografiske oplysninger. 


\title{
At lære sig "de kloge damers" sprog: Studerendes perspektiver på akademisk skrivning
}

\author{
Nana Clemensen, adjunkt, DPU, Aarhus Universitet \\ Lars Holm, lektor, DPU, Aarhus Universitet
}

\section{Videnskabelig artikel, fagfællebedømt}

Mange steder $i$ verden har universiteter gradvist forandret sig fra elite- til masseinstitutioner. Også i Danmark har et stigende antal "non-traditional students" (Lillis, 2001) affødt en tilsvarende interesse for akademisk skrivning, f. eks. i oprettelsen af akademiske skrivecentre og udgivelsen af akademiske skrivehåndbøger. Med afscet i en kvalitativ interviewundersøgelse, belyst i et sociokulturelt perspektiv på akademisk tekstproduktion, undersøger vi 12 studerendes erfaringer med konventioner for akademisk tekstproduktion på Padagogisk Antropologi - en kandidatuddannelse, som overvejende optager professionsbachelorer. Studerendes erfaringer fra undervisning, opgaveskrivning og studiegrupper analyseres i et academic literacies-perspektiv (Lea \& Street, 1998) med scrlig vagt på begrebet writer identity (Ivanič, 1998). Undersøgelsen viser, hvordan de studerende generelt orienterer sig mod en autoritativ forståelse af akademisk tekstproduktion, som de selv har ringe indflydelse på. I forloengelse heraf argumenterer vi for en Bakhtinsk inspireret dialogisme (Lillis, 2003) som en mulighed for at åbne et mere demokratisk rum for såvel studerende som undervisere.

\section{Indledning}

I de seneste årtier er der navnlig i den vestlige del af verden sket en markant udvidelse af den procentdel af en ungdomsårgang, der optages på en akademisk uddannelse. Fra politisk hold har man systematisk øget optaget af studerende på både etablerede og nye uddannelsesretninger, mens mange mellemlange uddannelser er blevet opgraderet til bacheloruddannelser, hvilket samlet set har øget den sociale spredning af studentermassen betragteligt (Lillis, 2001; Arneback m.fl., 2016). Hertil kommer, at der mange steder er sket en betydelig vækst i antallet af internationale studerende. Udviklingen fra nationalt forankrede eliteuniversiteter til internationalt orienterede masseuniversiteter med en langt større social, kulturel og sproglig diversitet end tidligere har været udfordrende for universitetsverdenen og har blandt andet medført en stærkt stigende faglig interesse for studerendes tilegnelse af akademiske skrivepraksisser (se fx Lea, 1995, Lea \& Street, 1998, 1999). Konkret har 
denne interesse manifesteret sig i opbygning og udvikling af skrivecentre på universiteter, i etableringen af skrivecenterfaglighed som et særligt universitært fagfelt (se fx Kinkead, 2015), i et utal af hjemmesider, hvor universiteter beskriver og redegør for praksisser for akademisk skrivning, og i et stort antal håndbøger og vejledninger, der introducerer sådanne praksisser for studerende (se fx Hutchison, 2005; Blückert, 2002; Hammershøj, 2008; Rienecker \& Jørgensen, 2005). Akademisk skrivning har såvel internationalt som her i landet fåt status af et "uomgængeligt indsatsområde og et nødvendigt studietilbud" (Krogh-Jespersen m.fl., 2001:11; se også Bjørk m.fl., 2003), der bør have karakter af "akademisk indkulturering og skriveoplæring af "basic writers"'"' (Rinecker, 2007:32). ${ }^{1}$

Den voksende institutionelle indsats for en sådan "akademisk indkulturering" af nye typer studerende tager typisk afsæt i en specifik tilgang til akademisk sprogbrug og tilegnelsen af den - nemlig som en afgrænset og forholdsvis fast defineret genre, som de studerende gennem mødet med universitetsverdenen og konkrete øvelser og opgaver socialiseres ind i. En styrke ved denne tilgang er, at den kan reducere studerendes usikkerhed i forhold til formelle genrekrav, at den kan give en generel forståelse for opbygning og tekstsammenhæng i en akademisk opgave, og at den kan sætte fokus på, hvad der betragtes som centrale træk i opbygningen af en argumentation eller analyse. En risiko ved samme tilgang er imidlertid, at de institutionelle magtforhold, spændinger og forandringspotentialer, der omgærder universitetsverden og dermed også akademisk sprogbrug, reduceres til statiske og ufravigelige genrekrav - og at den studerendes akademiske dannelsesproces hermed reduceres til et instrumentelt og ukritisk forløb (Lea \& Street, 1998).

I denne artikel har vi valgt at tage afsæt i en anden tilgang til akademisk skrivning og akademisk sprogbrug mere generelt - end den ovenfor beskrevne, nemlig som en forholdsvis dynamisk kommunikativ praksis, der løbende forhandles og forandres gennem interaktion mellem undervisere og studerende, mellem forskere og praktikere osv. Hermed trækker vi på forskningsfeltet academic literacies, der anskuer akademisk tekstproduktion som en lokal, socialt situeret praksis - det vil sige som en måde at tale og skrive på, som er uløseligt forbundet med de konkrete sociale og institutionelle kontekster, den forekommer i (Lea \& Street, 1998; Scott, 1999; Starfield, 2002; Lillis, 2003; Chandrasoma m.fl, 2004). Eftersom disse sociale kontekster ikke er statiske, men løbende forandrer sig - $\mathrm{fx}$ gennem tilkomsten af nye studerende, undervisere, videnskabelige metoder og begreber, politiske reformer osv. - kan den kommunikative praksis, der produceres i disse kontekster, heller ikke siges at være afgrænset eller statisk, men må anskues som evigt foranderlig. Det betyder dog ikke, at akademisk sprogbrug ifølge academic literacies-tilgangen er ubundet af regler og konventioner. Tværtimod må enhver interaktion forbundet med akademisk

\footnotetext{
${ }^{1}$ Se Otte, G. \& Mlynarczyk, R.W. (2010) redegørelse for diskursen om begrebet "basic writers".
} 
vidensproduktion ifølge denne tradition ses som indlejret i det magtforhold, der generelt tilskrives universitetet og dets repræsentanter som stærke autoriteter i samfundet - et magtforhold, der fx kommer til udtryk i det faktum, at undervisere kan give studerende karakterer, men ikke omvendt, ligesom forskere i højere grad har legitimitet til at vurdere praktikeres arbejde end omvendt. En samtale mellem studerende og undervisere - hvad enten den sker i undervisningen eller fx i relation til en eksamensopgave - kan altså langtfra ses som en "fri" interaktion, men derimod som en forhandling mellem aktører placeret i et asymmetrisk magtforhold (Clark \& Ivanič, 1997).

Vores analytiske fokus vil i denne artikel være på en gruppe studerendes konkrete erfaringer med og forestillinger om akademisk sprogbrug, som de har gjort sig i løbet af deres første tid på universitetet, såvel i undervisningen og vejledningen som i opgaveskrivningen og studiegruppediskussioner. Vi har af praktiske grunde valgt at tage afsæt i et studiemiljø, vi selv har stort engagement og indblik i, nemlig kandidatuddannelsen i Pædagogisk Antropologi, som vi begge underviser og vejleder på. Denne form for forskning i eget miljø vækker nogle særlige etiske og validitetsmæssige problemstillinger, som vi berører i afsnittet "Data og metode".

Det overordnede forskningsspørgsmål, som her søges besvaret, er, hvordan studerende oplever og beskriver deres erfaringer med akademisk tekstproduktion på kandidatuddannelsen i Poedagogisk Antropologi. Denne forskningsinteresse er grundlæggende motiveret af en nysgerrighed i forhold til, hvordan de studerende oplever et specifikt aspekt af universitetsverdenen (akademisk tekstproduktion), og af en overbevisning om, at viden herom kan være et væsentligt bidrag til udviklingen af den universitetspædagogiske praksis.

\section{Academic literacies - et sociokulturelt blik på akademisk tekstprodukti- on}

Forskningsfeltet academic literacies er en nyere gren af den sociokulturelle tradition, der ofte betegnes New Literacy Studies. Denne tradition adskiller sig fra kognitive eller funktionelle tilgange til literacy, der ser literacy som en individuel færdighed eller en kompetence, som kan eller bør kunne tilegnes af den enkelte. I modsætning hertil betragter vi med afsæt i New Literacy Studies literacy som noget, mennesker gør som en grundlæggende socialt situeret aktivitet (Barton \& Tusting, 2005). At forske i literacy fra dette perspektiv indebærer, at der sættes fokus på sociale aktiviteter, hvor tekster indgår (Barton \& Hamilton, 2000), og på de værdier og holdninger, bredere historiske og kulturelle baggrunde samt personlige erfaringer, som folk trækker på, når de indgår i den sociale praksis omkring literacy.

De centrale værker inden for den sociokulturelle tilgang, der beskæftiger sig med literacy som social praksis, er funderet i antropologiske og sociolingvistiske forsk- 
ningstraditioner og indebærer, at den forskningsmæssige opmærksomhed flytter fokus fra udvikling og måling af det enkelte individs kompetence til den sociale praksis omkring literacy i fællesskaber og netværk - det vil sige til socialt og institutionelt indlejrede forståelser af og konventioner omkring literacy og til de processer, der gør, at visse former for literacy samfundsmæssigt tillægges større værdi end andre (Scribner \& Cole, 1981; Heath, 1983; Street,1984). New literacy-studier er typisk baseret på dybdegående etnografiske undersøgelser af en afgrænset social virkelighed eller "felt" samt på en inddragelse af viden om de samfundsmæssige og historiske forhold, der dér gør sig gældende.

Lea og Streets (1998) undersøgelse blandt undervisere og studerende på et engelsk universitet fra slutningen af 1990'erne fremstår som et pionerarbejde inden for academic literacies-feltet. De beskriver her den akademiske verden som en institution præget af en række forskellige kommunikative praksisser - herunder forskellige tilgange til akademisk skrivning - og fremhæver desuden, hvordan der er forskellige tekstgenrer og måder at italesætte tematikker på inden for forskellige fagdiscipliner, som ikke altid stemmer overens. For at begå sig og finde sin egen "stemme" i universitetets virvar af (magt-)positioner og usynlige dagsordener må den studerende ifølge Lea og Street lære disse forskellige praksisser at kende sammen med konventionerne for deres anvendelse. På baggrund heraf kan det at skrive siges altid at indebære en form for identitetsarbejde, hvor forfatteren søger at positionere sig selv $\mathrm{i}$ forhold til de tekstlige konventioner, han eller hun forbinder med den pågældende genre, hvad enten det gælder personlige breve, avisartikler eller akademiske tekster. Dette identitetsmæssige perspektiv er blevet nærmere teoretisk og analytisk udfoldet og undersøgt i relation til akademisk tekstproduktion af Ivanič (1998) og Lillis (2001;2003) med afsæt i begrebet writer identity. I Lillis (2001) ses der længerevarende case-studier af tre studerendes identitetsprocesser i relation til akademisk tekstproduktion, der også inddrager individuelle livshistoriske perspektiver. Til forskel herfra ses der hos Ivanič (1998) et mere tværgående forskningsdesign, der er rettet mod at afdække "the nature of writer identity" (Ivanič, 1998:113) med empirisk afsæt i en undersøgelse af en mindre gruppe studerendes erfaringer og perspektiver.

Vi vil med inspiration fra Ivanič se nærmere på, hvordan de 12 Pædagogisk Antropologi-studerende forstår og positionerer sig selv i den akademiske tekstproduktion på den uddannelse, som de selv er en del af. Til forskel fra både Lillis og Ivanič retter vi således vores opmærksomhed mod studerende på en bestemt uddannelse, fordi vi antager, at forskellige videnskabelige erkendelsesinteresser inden for forskellige fag og fagområder ikke kan undgå at sætte deres præg på forventninger til og traditioner for akademisk tekstproduktion. 


\section{Data og metode}

Vores interesse for studerendes perspektiver på akademisk tekstproduktion blev oprindelig vakt gennem vores daglige virke som undervisere og vejledere ved kandidatuddannelsen i Pædagogisk Antropologi på det forhenværende Danmarks Pædagogiske Universitet (DPU), nu Danmarks institut for Pædagogik og Uddannelse under Aarhus Universitet. DPU har siden sin oprettelse som selvstændigt universitet i 2001 været landets største videreuddannelsessted for professionsbachelorer. I 2015 havde omkring 85\% af instituttets ca. 4.000 kandidatstuderende en baggrund som professionsbachelorer, mens ca. 10\% var universitetsbachelorer. Et flertal af de studerende har et eller flere års erhvervserfaring som færdiguddannede pædagoger, lærere, sygeplejersker etc. bag sig, når de påbegynder kandidatuddannelsen, og mange har inden da gjort sig store overvejelser om deres videre faglige og personlige udviklingsveje. Fra vores egne og vores kollegers løbende kommunikation med studerende i undervisningen og vejledningen ved vi, at kun en lille andel af de studerende generelt er vokset op i hjem, hvor en eller begge forældre har gennemført en videregående uddannelse, mens størstedelen er vokset op med faglærte eller ufaglærte forældre.

Kandidatuddannelsen i Pædagogisk Antropologi kan således siges at afspejle udviklingen fra forholdsvis homogene eliteuniversiteter til mere heterogene masseuniversiteter. Konkret udmønter denne udvikling sig blandt andet i en oplevelse af afstand og usikkerhed blandt mange studerende, navnlig over for de sproglige praksisser og konventioner - mundtlige såvel som skriftlige - som de forbinder med universitetet. Vores interesse har som før nævnt været at udforske de studerendes konkrete erfaringer med og perspektiver på disse praksisser og konventioner og belyse dem ud fra academic literacies-paradigmet - det vil sige ud fra en forståelse af akademiske praksisser og konventioner som indlejret eller situeret i en specifik social og institutionel kontekst, nemlig universitetsverdenen. Hermed ønsker vi at skabe øget opmærksomhed og viden om et centralt socialt og pædagogisk aspekt af universitetsog uddannelsesverdenen i dag, som for os at se har vigtig betydning for de studerendes samlede erfaring med og udbytte af deres tid på universitetet.

I forsommeren 2015 og igen i efteråret samme år interviewede vi 12 Pædagogisk Antropologi-studerende, som alle var i gang med deres første studieår. Vi rekrutterede disse studerende via fællesmails til hele årgangen af førsteårsstuderende i København (ca. 60 studerende), som vi ikke selv havde noget aktuelt underviser- eller vejlederforhold til. Hermed søgte vi at imødegå den ufravigelige asymmetri, der ifølge academic literacies-tilgangen kendetegner forholdet mellem studerende og universitetsansatte. Vi har gennem hele undersøgelsen søgt at tage forbehold for denne asymmetri og dens potentielle betydning for de studerendes deltagelse og bidrag og hermed validiteten af vores resultater - for eksempel ved at sikre de studerende 
fuld anonymitet og ved at indtage en åbent lyttende position med fokus på den enkelte studerendes erfaringsverden. Sådanne forbehold kan naturligvis ikke udjævne magtforholdet mellem studerende og universitetsansat, især eftersom samtalen her ensidigt initieres og defineres af den universitetsansatte (intervieweren) og også finder sted på universitetet. Men omvendt har vi som mangeårige undervisere og vejledere en særlig fortrolighed med de studerendes hverdag og erfaringer, som det kan være svært for en udenforstående at få adgang til.

Hvert interview fulgte en semistruktureret interviewguide (Spradley, 1979), varede 30-50 minutter og foregik individuelt, på nær ét hvor to studerende deltog sammen. I vores spørgsmål opfordrede vi som nævnt de studerende til at tage afsæt i deres egne konkrete erfaringer og synspunkter, fx: "Kan du fortælle lidt om, hvordan du oplever måden at arbejde med og tale om tekster på Pædagogisk Antropologi?" og: "Hvordan har din egen proces været i forhold til de implicitte eller eksplicitte forventninger, du har mødt på studiet, omkring det at skrive opgaver?". Samtlige 12 interviews har vi efterfølgende transskriberet og analyseret med inspiration fra academic literacies-litteraturen generelle vægtning af den studerendes personlige erfaringer og beskrivelser, hvilket vi uddyber i analyseafsnittet nedenfor.

Ud af de ca. 60 inviterede førsteårsstuderende viste ca. en tredjedel interesse, men flere faldt ret hurtigt fra på grund af tidspres. De resterende 12 studerende er valgt, fordi de havde ønske om og mulighed for at deltage, og de er således ikke nødvendigvis repræsentative for hverken den specifikke årgang eller studerende ved Pædagogisk Antropologi eller DPU mere generelt. Samlet set kan de dog alligevel siges at afspejle den generelle studentersammensætning på DPU i disse år, nemlig en overvægt af kvinder (9 ud af 12 af vores deltagere) og en bred faglig og social diversitet. Som kandidatuddannelsen i Pædagogisk Antropologi fordrer, har de alle en bachelorgrad inden for det pædagogiske felt, fx som pædagoger (7), ergoterapeut (1) eller inden for det humanistiske hovedområde (4), men deres alder, erhvervserfaringer, motiver og veje frem til netop denne kandidatuddannelse varierer bredt: Den yngste af dem er 25 år og har for nylig afsluttet en bacheloruddannelse ved Aalborg Universitet, mens den ældste er 45, uddannet pædagog og med mange års praksiserfaringer bag sig. En tredjedel af dem har mere end én påbegyndt bacheloruddannelse bag sig.

\section{Analyse}

I vores analyse af de i alt 154 siders interviewudskrifter har vi søgt at lade os lede af de 12 studerendes egne erfaringer og perspektiver på akademisk tekstproduktion, snarere end af en fast hypotese. Igennem omfattende læsninger har vi søgt efter mønstre og sammenhænge både inden for og på tværs af de studerendes beskrivelser, hvorefter vi har udvalgt og afgrænset en lang række citater, som vi dels fandt repræsentative for de studerendes forskellige perspektiver og dels fandt interessan- 
te ud fra den academic literacies-tilgang, der har inspireret vores undersøgelse, og som på et overordnet plan retter den forskningsmæssige opmærksomhed mod konventioner og normer for akademisk skrivning (Lillis, 2001). Denne ret løse, teoretisk inspirerede "bricolage-tilgang" lægger et stort fortolkningsansvar på forskeren og kan kritiseres for at være mindre gennemskuelig og validérbar end mere systematiske analysemetoder som kategorisering eller konversationsanalyse (Kvale \& Brinkmann, 2015: 303ff). Men som Kvale \& Brinkmann skriver, kan fremkomsten af "mange betydningsfulde interviewundersøgelser fra de seneste årtier ... tyde på, at det er mindre vigtigt at søge tilflugt i specifikke analytiske værktøjer, når man har en teoretisk viden om emnet for en undersøgelse og stiller teoretisk orienterede interviewspørgsmål" (ibid: 306).

På trods af den forholdsvis brede spredning i både alder og uddannelsesbaggrund viste læsningerne af materialet os nogle slående fællestræk imellem de 12 studerendes oplevelser af mødet med universitetsmiljøet på Pædagogisk Antropologi. Vi forventede således en højere selvsikkerhed omkring akademiske tekstkonventioner blandt de fire universitetsuddannede bachelorer og de fire forholdsvis nyuddannede professionsbachelorer end blandt de fire pædagoger, som havde været uddannet i mere end ti år, men vores læsninger viste os en gennemgående grad af usikkerhed blandt samtlige de 12 deltagere, navnlig omkring skriftlige tekstkonventioner på kandidatuddannelsen, som var vores primære interessefelt.

På baggrund af disse fællestræk har vi af pladshensyn og for at skabe større analytisk overblik valgt at fremstille de 12 studerendes erfaringer og perspektiver som refleksioner af en mere generel erfaring blandt studerende på kandidatuddannelsen i Pædagogisk Antropologi. Ulempen ved denne tilgang er, at vi - og læseren - ikke får mulighed for at gå i dybden med hver enkelt studerendes perspektiv, hvilket utvivlsomt også kunne føre interessante analyser med sig. Ved at indsætte og identificere citater fra alle 12 deltagere giver vi imidlertid læseren et lille indblik, dels i de enkelte studerendes erfaringsverdener og dels i det datamateriale, der har ligget til grund for vores analytiske slutninger. Vi har ikke videnskabeligt belæg for at vurdere, hvorvidt disse slutninger kan vække genklang i studiemiljøer på andre kandidatuddannelser, men vi berører emnet i den afsluttende diskussion.

\section{Hvordan udtrykker man sig her?}

I deres svar på spørgsmålet om, hvad der især har været udfordrende ved mødet med kandidatstudiet, bruger mange af de studerende (9 ud af 12) udtryk som "at knække den akademiske kode" eller "at lære det akademiske sprog":

“Det er især det dér akademiske sprog. Hvis jeg kan sige en sætning, hvor jeg kan bruge et eller andet ord eller begreb, som jeg normalt ikke vil bruge, så kan jeg tænke: "Jeps, der var den. Jeg fik et ord ind i sætningen". Men det synes jeg, har været rigtig svært. Også fordi det bliver brugt i undervisningen, og det skal det selvfølgelig, 
men hvad fanden var det nu, det dér betød, og så lige skrive det ned, så jeg kan slå det op, når jeg kommer hjem". Karin (44), uddannet paedagog

“Det er jo den dér akademiske måde at skrive på. I starten oplevede jeg den som fremmedgørende. Det kan være svært at gå ind til en vejleder og bede om det, man præcist gerne vil have noget af, hvis man bliver usikker på, om det er for dumt at stille det spørgsmål. Især i første semester kan det være svært, indtil man har snakket med sine medstuderende og mærket, at mange af dem har det på samme måde. De er bare bedre til at gå stille med det". Cecilie (25), samfundsvidenskabelig bachelor

“Jeg synes, jeg har knækket koden til det akademiske sprog, som vi skriver. Hvor man nogle gange kan sidde og tænke, at det er egentlig ikke så vigtigt, om du har ret eller ikke ret, bare det akademisk lyder overbevisende. Og så sådan et ord som abonnere, at nogen abonnerer på en eller anden ting. Det er jeg begyndt at bruge i de her kandidattekster, det har jeg ikke brugt meget før på bachelorniveau". Katrine (25), humanistisk bachelor

Karakteristisk for disse beskrivelser er oplevelsen af en særlig sprogbrug blandt undervisere, vejledere og i tekster på universitetet - en sprogbrug, som de studerende nok kan identificere og (delvist) afkode, men som de ikke umiddelbart oplever at beherske eller have adgang til selv. Denne særlige sprogbrug fremstilles generelt som en etableret og institutionelt afgrænset "kode", som den enkelte studerende skal "knække" for ikke at fremstå dum eller uvidende f. eks. i skriftlige opgaver, ved vejledningen eller under plenumdiskussioner. De studerende giver således udtryk for en forståelse af akademisk sprogbrug som en på forhånd givet færdighed, som de universitetsansatte - i modsætning til de studerende - til fulde besidder og har patent på at definere og afgrænse. Hermed bidrager de studerende selv til at bibeholde et asymmetrisk, distanceret forhold mellem universitetet og sig selv.

Hvem bør man voere her?

Blandt de interviewede studerende bemærker vi en grundlæggende usikkerhed over for undervisere og vejlederes forventninger til deres præstation, navnlig i skriftlige opgaver - dels over for forventningernes konkrete natur, og dels over for deres egne evner til at efterleve dem. Flere beskriver, hvordan de i arbejdet med analyseøvelser og skriftlige opgaver forventes at forholde sig selvstændigt til teorier og begreber, mens de samtidig møder kritik for at tilkendegive deres personlige, normative holdninger. Hermed adskiller universitetets kriterier for dét "at mene noget" sig fra dem, de typisk har mødt tidligere i deres uddannelsesforløb:

"På pædagoguddannelsen måtte vi gerne mene mere. Det var også mere problemorienteret, og du skulle have en løsning ... Det her med lige pludselig at være tilbage igen og ikke rigtig måtte mene noget om noget, det skal man lige øve sig i igen". Christina (39), uddannet paedagog og sygeplejerske 
"Hvis der var noget, der var et chok, så var det det dér selvstændige og skriftlighed". Maria (45), uddannet paedagog

"Jeg startede ikke ud med en assumption om, at jeg skulle skrive "jeg synes" og "jeg mener". Men hvordan får man alligevel skrevet noget af dét, man mener, frem? Altså bare gennem brillerne på nogle andre. Det er dét, der er hele opgaven i det her. Og det dér skal man finde ud af, hvordan man gør. Der er højere krav her til min argumentation. Man kan ikke charme sig igennem. Argumentationen skal kunne holde til noget mere". Peter (38), professionsbachelor og samfundsvidenskabelig bachelor

“I forhold til min [bachelor-]baggrund fra universitetet synes jeg, det er en forskel [på pæd. antropologi], at man skal træde mere frem, at man skal give sig selv mere til kende. Det har jeg slet ikke været vant til på bachelor, der var det ikke i orden at have en selvstændig mening eller tanke om noget. Især når man skriver, er det mere OK at komme frem og tænke selvstændigt i forhold til at udvikle fx teoretiske begreber. Det synes jeg har været meget nyt, at man skal, man giver sig selv lov til det, til selv at begynde at tænke og også at skrive: "Jeg synes, at man kan'"'. Ulrik (44), humanistisk bachelor, samt bl. a. to diplomuddannelser

Udsagn som disse vidner om en igangværende udvikling hos de studerende af deres writer identity - altså den "stemme", de hver især taler med i deres skriftlige opgaver og øvelser (Ivanič, 1998). Ifølge Ivanič aktiverer skriveprocessen tre gensidigt forbundne identitetsaspekter hos forfatteren, nemlig 1) det "autobiografiske selv", altså de private og professionelle livserfaringer, forfatteren tager med sig ind i skrivearbejdet, 2) det "diskursive selv", altså det selvbillede, forfatteren bevidst eller ubevidst tegner af sig selv i den konkrete tekst, og 3) "det autoritative selv" (the self as author), altså den autoritet og selvstændighed, hvormed forfatteren formår at formidle sit budskab gennem teksten (Ivanič 1998: 24ff).

Den usikkerhed, de studerende ovenfor udtrykker omkring dét at "mene noget" i universitetsopgaver, kan måske forklares med oplevelsen af et modsætningsforhold mellem deres autobiografiske selv - altså de livs-, erhvervs- og uddannelsesmæssige erfaringer, de hver især har med sig i baggagen, når de påbegynder studiet - og det autoritative selv, de forventes at etablere over for de temaer, teorier og begreber, de behandler i deres opgaver. Som relativt nye medlemmer af det akademiske praksisfællesskab finder mange studerende det både svært og utroværdigt at tale med den samme autoritet og alvidenhed, som de møder blandt undervisere og i fagtekster på studiet. Samtidig oplever de studerende, at deres evne til at etablere et sådan autoritativt selv, såvel i skriftlige opgaver som i mundtlige oplæg, er helt central for de universitetsansattes bedømmelse af deres faglige præstation, hvilket for mange studerende medfører en form for identitetskrise, navnlig i det første halve til hele år på studiet, fordi det selvbillede eller den "stemme", de forventes at præsentere, ikke harmonerer med det, de hidtil har identificeret sig med. I vores interviews giver stort 
set alle de studerende således udtryk for en lettere eller mere dybdegående tvivl om deres egne evner og forudsætninger for at begå sig i den akademiske verden:

"Man kommer jo til at føle, at man er øh ... sådan lidt smådum, var jeg lige ved at sige. Jeg tænker nogle gange det dér med, jamen: "Hvorfor er det for det første, at jeg ikke kan lidt af det her i forvejen?". "Hvordan har jeg overhovedet ...?". Det har jeg tit undret mig over...". Lisa (27), uddannet poedagog

"Det er jo de kloge damer, der står på podiet og underviser. Der er da en respekt og en distance på en eller anden måde, hvor man tænker: "Hold da op"'". Susanne (34), uddannet poedagog

"Jeg er den første i min familie, der er student, ik'? Og den første, der tog en mellemlang videregående uddannelse, og jeg er fandeme også den første, der tager en universitetsuddannelse, og jeg har hele tiden tænkt, at: "Jeg er for dum til at gå på universitetet, det kan jeg ikke udholde, jeg skal have noget praktisk og et eller andet". Og der sidder mange [på holdet], der er lidt, der er ret usikre". Mette (35), uddannet ergoterapeut, samt. bl. a. en diplomuddannelse

"Jeg synes tit jeg famler, når jeg skal prøve at forklare noget. Og jeg kommer jo også nemt til at sammenligne mig med dem, som måske er lidt yngre og lige kommer fra en eller anden bachelor, og som ligesom har sproget på rygraden, eller hvad man nu skal sige. Så jeg har måske holdt mig lidt tilbage nogle gange i forhold til at sige noget, fordi jeg tit har tænkt: "Jeg kan slet ikke formulere det, jeg egentlig gerne vil sige"... øhm ... "og det lyder nok også dumt"'". Dorte (40), uddannet poedagog

Overordnet tegner flere studerende altså et lidt dystert billede af studielivet som præget af oplevelser af usikkerhed og mindreværd, ikke bare i mødet med tekster, undervisere og deres svært aflæselige sprog og forventninger, men også over for deres medstuderende. Vores indtryk af det sidste aspekt bestyrkes af, at kun én af de 12 deltagere hidtil har valgt at samarbejde med en eller flere medstuderende omkring det konkrete skrivearbejde forbundet med øvelser og opgaver, selv om de alle er eller har været tilknyttet en studiegruppe undervejs på studiet. Derimod centrerer studiegruppesamarbejdet sig for de fleste om læsning og diskussion af fagtekster og underviseroplæg, igen med vægt på ønsket om at "knække" en fast afgrænset kode:

"Nu her op til eksamen har vi siddet nogle, der har været på det dér "professionelt"halløj [temakursus om "Professionelle identiteter", red.] og hjulpet hinanden: "Hvad var det nu lige hovedpunkterne var hos ham dér Max Weber, hvad var det nu det dér xx handlede om, hvad har du skrevet i dine noter, og hvad har jeg skrevet i mine, og så sagde hun også noget om det her, gad vide hvad hun mente med dét? Var det ikke sådan her, eller kan man egentlig bruge xx på den her måde?" Altså vi har diskuteret tekster". Naja (26), uddannet paedagog 
Studiegrupper fremhæves af næsten alle de studerende som en givtig arena for tekstlæsning og social støtte i hverdagen, men i langt de fleste tilfælde ikke som et relevant rum til drøftelse af akademisk tekstproduktion.

Alt i alt læser vi de interviewede studerendes erfaringer og perspektiver som et væsentligt bidrag til en forståelse af akademisk tekstproduktion som lokal social praksis på en videregående uddannelsesinstitution: DPU, der på sine kandidatuddannelser er karakteriseret ved at have en høj procentdel af studerende med en professionsbachelorbaggrund og ved at så godt som alle universitetsbachelorer kommer fra andre universiteter. Uanset deres uddannelsesbaggrund udtrykker de studerende i vores undersøgelse alle oplevelsen af at være placeret i en uddannelseskultur med et miljø omkring akademisk tekstproduktion, der er præget af en tilsyneladende noget elitær, lukket og entydig praksis. At være en del af dette miljø forbinder mange studerende med en følelse af usikkerhed, ikke kun over for undervisere og vejledere, men også over for deres medstuderende. I studiegruppen henter mange social og faglig sparring omkring pensum og studiehverdagen mere generelt, men kun få vælger at indlemme andre i produktionen af deres egne tekster, selv om denne del af studiet generelt opleves som den mest udfordrende.

\section{Konklusion og diskussion}

Samlet set viser vores undersøgelse, at der blandt de interviewede studerende eksisterer en forståelse af den akademiske genre som ret entydig og identificérbar. De studerende er af den opfattelse, at der findes en særlig og "rigtig" måde at udtrykke den individuelle stemme i en akademisk tekst på, og at der blandt undervisere og vejledere er en ret udbredt konsensus om, hvordan en akademisk tekst skal se ud. Denne forståelse af akademisk tekstproduktion, som Lea \& Street (1998) benævner en "study-skills approach", indebærer en forestilling om akademisk tekstproduktion som et sæt fastlagte tekniske færdigheder, der bør læres med henblik på at skabe et produkt af en ganske særlig karakter.

Samtidig oplever mange studerende en ikke ubetydelig forskel i forhold til akademisk tekstproduktion på kandidatuddannelsen og på tidligere adgangsgivende akademiske uddannelser - bacheloruddannelser eller professionsbacheloruddannelser. Denne situation kan fra et kandidatuddannelsesperspektiv læses og forstås som en situation, hvor de studerende er blevet fejlsocialiseret til akademisk tekstproduktion og har lært noget "forkert", inden de starter på kandidatuddannelsen. Anlægges et perspektiv af denne karakter, kan det forekomme relevant at opfordre de studerende til at glemme, hvad de tidligere har lært. Men en sådan velkomst til studiet på en kandidatuddannelse er for os at se uhensigtsmæssig, fordi den underkender de studerendes "writer identity" (Ivanič, 1998) på en måde, der kan skabe betydelig usikkerhed, samtidig med at ansvaret for den ønskede "resocialisering" af de studerende placeres meget tungt på undervisernes skuldre. 
For os at se er det centrale problem i forhold til de studerendes perspektiver på akademisk tekstproduktion ikke, at der opstår usikkerhed eller kriser, men at forståelsen af akademisk tekstproduktion inden for rammerne af en snæver og på forhånd fastlagt "study-skills approach" skaber et meget instrumentelt orienteret perspektiv på akademisk tekstproduktion, der ikke åbner for en bredere dialog om vidensskabelse i universitetsverdenen.

På baggrund heraf vil vi plædere for en fælles undersøgelse blandt undervisere og studerende af den sociale praksis omkring akademisk tekstproduktion. Dette vil i bedste fald kunne åbne for en bred sproglig etnografisk nysgerrighed og tilbyde såvel studerende som undervisere et mere dialogorienteret udgangspunkt for samarbejdet omkring skabelse af akademiske tekster.

En sådan drøftelse af akademiske tekstskabelse kan, som Lillis (2003) påpeger, hente inspiration i den russiske sprogforsker Mikhail Bakhtins begreb om det dialogiske, der omfatter to forskellige niveauer. Der er for det første tale om et deskriptivt, intertekstuelt niveau, hvor tekster og ytringer ses som grundlæggende dialogiske, som rettede og som altid indlejret i en kæde af kommunikation. Et intertekstuelt perspektiv kan give de studerende indsigt i, at akademisk tekstproduktion ofte er et langt mindre individuelt fænomen, end det måske umiddelbart tager sig ud. Skabelse af akademisk viden sker altid i en dialog med andre tekster og andre stemmer, som - måske, måske ikke - er fysisk til stede og med i skriveprocessen.

For det andet ses dialog hos Bakhtin som noget, der skal kæmpes for i et spændingsfelt mellem to poler. Den ene pol kalder han centripetal monologisme, karakteriseret ved en autoritativ diskurs, der grundlæggende kun giver plads til én sandhed og én stemme. Den anden kalder han centrifugal dialogisme, der i modsætning til den centripetale rummer mange sandheder, mange stemmer og hybriditet. Hvis en autoritativ diskurs og praksis omkring akademisk tekstproduktion dominerer undervisningen, vil der for os at se være en tendens til, at de studerende gøres til objekter i en akademisk indkulturering, hvor den akademiske vidensproduktion i meget væsentlig grad indskrives i et statisk og reproduktivt tekstlandskab. Er diskursen derimod i højere grad dialogisk orienteret, kan det åbne for en praksis omkring tekstproduktion, hvori den studerende får mulighed for selv at diskutere sin tekst og vurdere velfungerende og mindre velfungerende aspekter i forhold til den studerendes egne parametre og intentioner med teksten. En sådan tilgang vil kunne bidrage og give mere plads til nye måder at skabe betydning og viden på i den akademiske verden.

På baggrund af samtaler med kolleger på tværs af uddannelser og fakulteter er det vores indtryk, at den oplevelse af universitetsmiljøet, som vi her har analyseret frem, ikke begrænser sig til kandidatuddannelsen i Pædagogisk Antropologi, men tværtimod afspejler den sociale og institutionelle virkelighed, som mange studerende møder og forbinder med universitetet i dag (se fx Højberg \& Martinussen, 2015). Denne 
virkelighed er formet af en lang række sociokulturelle, historiske og politiskøkonomiske faktorer, herunder de senere års uddannelsespolitiske reformer både i Danmark og i en bredere global kontekst, der som beskrevet i indledningen har medført store forandringer af både sammensætningen og omfanget af universitetsstuderende, såvel som af de økonomiske og strukturelle rammer, der generelt omgiver universitetsuddannelser i dag.

Det asymmetriske magtforhold mellem underviser og studerende og tilstedeværelsen af bestemte forventninger til udformningen af universitetsopgaver forsvinder ikke, ved at man orienterer sig i dialogisk retning, men i den daglige praksis kan magten lejlighedsvis og i større eller mindre grad sættes i parentes. Vores argument er grundlæggende, at det vil fremme både de studerendes læreprocesser og den fortsatte udvikling af universitetsverdenen at åbne et Bakhtinsk inspireret dialogisk rum for arbejdet med akademisk tekstproduktion. Det kunne give plads til nye stemmer, nye praksisser omkring vidensproduktion og åbne for nye, studentergenererede erfaringer med og perspektiv på akademisk tekstproduktion og måske også for nye måder at tænke gyldige repræsentationer af viden på.

Nana Clemensen (f. 1976) er ansat som adjunkt ved Danmarks Institut for Uddannelse og Poedagogik, DPU, Aarhus Universitet. Hun forsker i sprogsocialisering blandt børn og unge i forskellige fallesskaber som familien, uddannelsesinstitutionen og børnegruppen. Hun har tidligere studeret børns indbyrdes forhandlinger af sociale roller, relationer og magtforhold i et zambiansk landsbysamfund.

Lars Holm (f. 1952) er ansat som lektor ved Danmarks Institut for Uddannelse og Paedagogik, DPU, Aarhus Universitet. Han forsker i literacy og sprog som social praksis. Han har tidligere forsket i undervisningen i dansk som andetsprog for voksne og i heldagsskoler og forsker for øjeblikket i praksis omkring institutionelle vurderinger af børns sprog og literacy inden for henholdsvis dagtilbudsområdet og folkeskoleområder.

\section{Litteratur}

Arneback, E., Englund, T. \& Solbrekke, T. D. (2016). Writing in and out of control. A longitudinal study of three student teachers' experiences of academic writing in preschool teacher education. Nordic Studies in Education, 2016:3, 211-228.

Barton, D. \& Hamilton, M. (1998). Local Literacies: Reading and Writing in One Community. London: Routledge.

Barton, D. \& Tusting, K. (eds.) (2005). Beyond Communities of Practice. Language, Power and Social Context. Cambridge: Cambridge University Press.

Bjørk, L. m.fl. (red) (2003). Teaching Academic Writing in European Higher Education. Dordrecht: Kluwer Academic Publishers. 
Blückert, A. (2002). Skrivarstugor och loggböcker: En översikt över ideér och insatser kring studenters skrivande. Uppsale: Uppsalea Universitet.

Chandrasoma, R., Thompson, C. \& Pennycook, A. (2004). Beyond Plagiarism: Transgressiv and Nontransgressiv Intertextuality. Journal of Language, Identity and Education 3(3), 171-193.

Clark, R. \& Ivanič, R. (1997). The Politics of Writing. London: Routledge.

Hammershøj, Lars Geer (2008). At forholde sig akademisk: om opgaveskrivning på lange videregående uddannelser. København: Danmarks Pædagogiske Universitets Forlag.

Heath, S. B. (1983). Ways with Words. New York: Cambridge University Press.

Hutchison, H. (2005). The Good Writing Guide. University of Aberdeen: Student Learning Service.

\section{https://www.abdn.ac.uk/socsci/documents/GoodWritingGuideAnthro.pdf}

Højberg, K. \& Martinussen, M. (2015). “Er jeg akademiker nok?” - studenterkampe om legitim uddannelseskultur. Dansk Universitetspoedagogisk Tidsskrift 18, 7-24

Ivanič, R. (1998): Writing and identity. The discoursal construction of identity in academic writing. Amsterdam: John Benjamins Publishing Company.

Kinkead m.fl. (2015). The International Writing Centers Association at 30: Community, Advocacy, and Professionalism.

http://writingcenters.org/wpcontent/uploads/2015/02/IWCA30Anniversary_article_kinkead_et_al.pdf

Krogh-Jespersen K., Kuhlmann, J. \& Striib, A. (2001). Forord til den danske udgave. I Dyste, F.; Hertzberg, F. \& Hoel, T. L. (2001). Skrive for at loere - faglig skrivning i de videregående uddannelser. Århus: Klim.

Kvale, S. \& Brinkmann, S. (2015). Interview. Det kvalitative forskningsinterview som håndvœrk. 3. udgave. København: Hans Reitzels forlag

Lea, M. (1995). "I thought I could write until I came here". I Graddog, D. \& Thomas, S. (eds): Language in a Changing Europe. S. 64-72. Clevedon: Multilingual Matters.

Lea, M. \& Street, B. (1998). Student writing in Higher Education; an academic literacies approach. Studies in Higher Education. 23(2), 157-172.

Lea, M. \& Street, B. (1999). Writing as academic literacies: understanding textual practices in higher education. I Candlin, C \& Hyland, K. (eds.): Writing: Texts, Processes and Practices.S. 62-81. London: Longman

Lillis, T. (2001). Students writing. Access, Regulation, Desire. London: Routledge. 
Lillis, T. (2003). Student Writing as "Academic Literacies": Drawing on Bakhtin to Move from Critique to Design. Language and Education, 17(3), 192-207.

Otte, G. \& Mlynarczyk, R. W. (2010). Basic Writing. West Lafayette: Parlor Press and The WAC Clearingshouse.

Rienecker, L. (2007). Skrivning og kunnskapsbygging i høyere utdanning - hva vet vi, hva trenger vi å vite? I Matre, S. \& Hoel T. L. (red.), Skrive for nåtid og framtid. Skriving og rettleiing i høgre utdanning. Bd.2, s. 32-45. Trondheim: Tapir.

Scott, M. (1999). Agency and subjectivity in student writing. I Jones, C., Turner, J, \& Street, B. (red.) Students Writing in the University: Cultural and Epistemological Issues. Amsterdam: Benjamins.

Scribner, S. \& Cole, M. (1981). The psychology of Literacy. Cambridge, MA: Harvard University Press.

Spradley, J. P. (1979). The ethnographic interview. New York: Holt, Rinehart and Winston.

Starfield, S. (2002). "I' m a Second-Language English Speaker": Negotiating Writer Identity and Authority in Sociology One. Journal of Language, Identity and Education, 1(2), 121-140.

Street, B. (1984). Literacy in Theory and Practice. Cambridge: Cambridge University Press. 